\title{
TRANSTHYRETIN QUATERNARY AND TERTIARY STRUCTURAL CHANGES FACILITATE MISASSEMBLY INTO AMYLOID
}

\author{
BY JEFFERY W. KELLY, WILFREDO COLON, ZHIHONG LAI, \\ HILAL A. LASHUEL, JENNIFER MCCULLOCH, SANDRA L. MCCUTCHEN, \\ GRETA J. MIROY, and SCOTT A. PETERSON
}

Department of Chemistry, Texas A\&M University, College Station, Texas 77843-3255

I. Background and Introduction $\ldots \ldots \ldots \ldots \ldots \ldots \ldots \ldots \ldots \ldots \ldots, 161$

A. The Role of Conformational Changes in Human Amyloid Disease ... 161

II. Understanding the Mechanism of Transthyretin Amyloid Fibril Formation in Vitro under Simulated Lysosomal Conditions $\ldots \ldots \ldots \ldots \ldots \ldots \ldots . \quad 167$

A. Quaternary Structural Changes within TTR as a Function of $\mathrm{pH} \quad \ldots . \quad 167$

B. Tertiary Structural Changes within TTR as a Function of $\mathrm{pH} \ldots \ldots \ldots 169$

C. A Model of the Monomeric Amyloidogenic Intermediate ........ 173

III. Understanding the Mechanistic Basis by Which the FAP Mutations

Function To Cause Early Onset Amyloid Disease ............... 175

A. Biophysical Studies on the FAP-Associated TTR Variants $\ldots \ldots \ldots \ldots \quad 175$

IV. Therapeutic Strategies for Intervention in TTR Amyloid Disease ....... 178

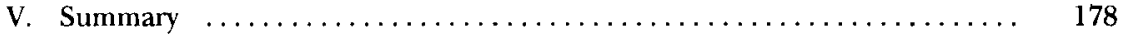

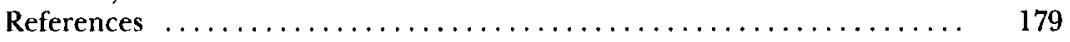

\section{Background AND InTroduction}

A. The Role of Conformational Changes in Human Amyloid Disease

\section{Conformational Change Hypothesis for Amyloid Fibril Formation}

Biophysical studies on transthyretin (TTR) and work on other amyloidogenic proteins suggest that amyloid fibril formation occurs as a result of conformational changes linked to a self-assembly process in the majority of the 16 normally soluble and functional human proteins (Kelly, 1996). The largely insoluble amyloid fibrillar cross- $\beta$-sheet quaternary structure formed from these proteins appears to have a common core structure (Kelly, 1996; Kelly and Lansbury, 1994; Lansbury, 1992). The observation that apparently unrelated proteins can form amyloid having a common tertiary and quaternary structure can be rationalized by considering the possibility that their structural similarity is not due to their normally folded structures. Instead, the amyloidogenic proteins appear to be related by the ability of at least a portion of their structures to undergo a conformational change affording an amyloidogenic interme- 